\title{
O PODER E A MORTE
}

JOSE MATTOSO

Arquivos Nacionais Torre do Tombo

(Lisboa, Portugal)

\section{SUMARIO}

1. Os túmulos.- 2. O poder divino do rei.- 3. O luto cósmico.- Bibliografia.

A "domesticaçāo da morte" de que fala Philippe Ariès, como sendo uma das características da atitude perante a morte das sociedades tradicionais, antes do século XVII', nāo significa propriamente uma ausência generalizada do medo que ela sempre infundiu aos homens. Foi apenas um modelo de comportamento destinado, precisamente, a esconjurar o medo e a saber conviver com a morte, tentando difundir uma atitude de auto-domínio por intermédio de uma solene ritualizaçāo do decisivo e terrível momento em que se abandona o mundo dos vivos. Como modelo de comportamento foi lenta e persistentemente formado no Ocidente Cristão sucedendo a outros adoptados por sociedades mais antigas. Estes, baseados em crenças e concepções profundamente enraizadas no inconsciente colectivo, deixaram, por vezes, os seus vestígios em práticas, costumes e rituais que desafiaram os séculos, através de incessantes adaptações e transformações. pp. 13-36.

I"La mort apprivoisée" é o célebre título do primeiro capítulo da obra de Ph. ARIÈS, 1977, 
Algumas das mais persistentes dessas práticas estão relacionadas com a morte dos chefes. Se o desaparecimento de um indivíduo normal perturba a comunidade, sobretudo os seus familiares mais íntimos, o de alguém que exerce a autoridade sobre o seu conjunto atinge-a de uma maneira bem mais profunda, porque afecta todos os seus membros. Com efeito, o chefe constitui o pólo visível da comunidade e como que assegura a sua persistência no tempo. Arbitra e julga os conflitos internos e, portanto, garante a sua coesão colectiva; ouve os mais sábios e experientes e supera as eventuais divergências dos seus pareceres, assumindo a responsabilidade da decisão final; vigia o cumprimento dos costumes e pune os transgressores; chefia os guerreiros que combatem os inimigos. Se a comunidade consegue formar um todo orgânico, em que cada membro tem o seu lugar e obtém segurança e ajuda, deve-o ao chefe a quem entregou a autoridade e a quem confiou o poder. Por isso, se ele desaparece, não é toda a comunidade que fica gravemente ameaçada? A sua morte aparece, portanto, como uma ameaça de morte para a própria comunidade; afecta todos os seus membros. Daí o medo e perturbação colectiva que o falecimento do chefe acarreta ${ }^{2}$.

A íntima relação do chefe com a comunidade explica que os rituais praticados por ocasião da sua morte sejam particularmente solenes, grandiosos e expressivos e que surjam sempre como uma manifestação de poder: além de exigirem o concurso de toda a comunidade, procuram exprimir a ideia de que o chefe permanece, de alguma maneira, e continua a exercer o seu poder, ainda para além da sua morte. As soluções adoptadas para significar esta ideia são as mais variadas possível. Os túmulos em matérias perduráveis, como a pedra ou o bronze, a sua grandiosidade e imponência, as riquezas que junto dele se acumulam ou ostentam, o concurso ordenado e ritualizado do maior número possível de participantes, a construção de monumentos em sua memória, a elaboração de epitáfios e inscrições comemorativas, e outros meios do mesmo género constituem algumas das mais conhecidas expressões dessa mesma convicção. Com efeito, não se destinam apenas a lembrá-lo como protagonista de um passado perdido, mas também a afirmar que ele representava qualquer coisa que se pretenderia imortal, permanente, capaz de desafiar o tempo. Por isso, os

\footnotetext{
'"A morte de um chefe determina no corpo social uma desorientação profunda, que, a prolongar-se , pode trazer graves consequências": R. HERTZ, 1990 (1917), p. 47; ver mais adiante o $3^{\circ}$ parágrafo desta comunicação; cf. também L.-V. ThOMAS, 1980, pp. 449-452.
} 
monumentos erguidos aos chefes não pertencem apenas aos que tomam o seu lugar como sucessores. Pertencem também à comunidade que julga não poder subsistir sem o chefe. Assim, os túmulos e monumentos que o lembram terão de constituir marcas indeléveis, capazes de desafiar a usura do tempo e de resistir a todas as mutações. São uma referência permanente para a própria comunidade, sinal visível de uma coesão que se pretende indestrutível, e, por isso, um apelo para que ela se mantenha apesar has mudanças introduzidas pela chefia do sucessor.

A permanência do poder, porém, não se exprime apenas por meio dos sinais, por assim dizer abstractos e passivos, da durabilidade e da grandeza dos túmulos e dos monumentos. As crenças na sobrevivência dos mortos e na protecção que os antepassados asseguram aos seus descendentes transformam-nos também em sinal visível de um poder que se julga permanecer activo e que por isso mesmo continua a proteger toda a comunidade, mesmo depois da morte do seu chefe. Com efeito, imagina-se a comunidade dos mortos à imagem e semelhança da comunidade dos vivos. E assim como estes não podem subsistir sem um chefe, assim também os antepassados têm os seus chefes ou herois. À protecção que os antepassados em geral concedem aos vivos, sobretudo aos seus parentes, corresponde a que se atribui aos herois de outrora, depois de mortos, em favor de toda a comunidade.

Como é evidente, o sucessor, qualquer que seja o título que o legitima --o sangue, a eleição ou a propriação do lugar pela força-- incarna o mesmo poder que o seu antecessor exerceu. Também esta ligação com ele é expressa das maneiras mais variadas nas diversas civilizações e culturas. A transmissão dos símbolos do poder, como a coroa, o cetro, o trono, etc., o papel desempenhado pelo sucessor nas exéquias, a forma como se sucedem as cerimónias funerárias e as de entronização podem ser alguns dos indícios das concepções que determinadas comunidades adoptam acerca da continuidade do poder. A escolha dos sinais que o dizem não depende só das tradições que se foram constituindo ao longo dos séculos; resulta muitas vezes do grau de estabilidade que a sociedade alcançou: as épocas de crise são normalmente propícias a demonstrações mais expressivas daquilo mesmo que se pretende superar, ou seja, a ruptura da coesão interna e a desordem social que o hiato do poder normalmente traz consigo.

De qualquer maneira, a morte dos chefes e dos reis produz quase sempre uma profunda perturbação colectiva. É lógico que essa perturbação seja tanto maior quanto mais frágil é a comunidade ou mais ameaçadora a 
crise social a que eventualmente esteja associada. Se ela surge espontâneamente, pode-se também esperar que o sucessor acentue artificialmente as suas expressōes, porque ela traz consigo o desejo colectivo de um novo chefe e a submissão antecipada à sua autoridade. Amplificado artificialmente ou não, o que se verifica é que quanto maior é o sentimento de perturbação, tanto maior é o desejo de um salvador. Foi o que aconteceu com o sebastianismo. E antes disso não chamaram "Messias de Lisboa" ao Mestre de Avis, como refere Fernão Lopes? ${ }^{3}$. Fora de épocas de crise profunda como estas, os indícios da perturbação deixaram, em Portugal, poucos vestígios aparentes. Encontram-se algumas vezes, porém, sobretudo em épocas mais recuadas, sob uma forma ritualizada. Os rituais que exprimem e dramatizam a perturbação causada pela morte constituem, então, eles próprios, práticas colectivas destinadas a socializar as energias libertadas pela perturbação e o medo de insegurança. É neste sentido que se devem interpretar os prantos, lamentações e formas de luto colectivos. De facto, as cerimónias fúnebres suscitadas pela morte régia procuram justamente esconjurar a perturbação, quer transformando em liturgia a participação colectiva que aperta os laços da solidariedade, quer por uma expressão dramatizada da própria perturbação, como são os lamentos fúnebres, quer pela ostentação de um poder que se assemelha ao potlacht. $O$ que pretendemos aqui é justamente verificar que modalidades históricas revestiram no ocidente da Península Ibérica estes processos rituais cujo significado fica assim exposto na sua generalidade.

Tendo já noutra ocasião tratado da morte dos reis na cronística peninsular anterior a Afonso X, $O$ Sábio ${ }^{4}$, gostaria agora de retomar o problema de forma mais ampla, e averiguando o que a historiografia peninsular permite dizer acerca dos rituais da morte régia em Portugal, Leão e Castela até à época de D. Manuel.

${ }^{3} \mathrm{Cf}$. Margarida Garcez Ventura, $O$ Messias de Lisboa. Um estudo de mitologia política (1383-1415), Lisboa, Cosmos, 1992.

4J. Mattoso, A morte dos reis na cronistica pré-afonsina, in "Estudos medievais", 10 (1993), pp. 79-95. 


\section{OS TÚMULOS}

Pouco se sabe acerca dos rituais funerários dos reis da época asturiana. As fontes litúrgicas, que poderiam trazer alguma informação a tal respeito, nada dizem ${ }^{5}$. A tradição historiográfica asturiana e castelhanoleonesa, porém, preservou os vestígios de uma memória precisa acerca da mutação verificada com a transição dos costumes góticos para os asturianos pelo que diz respeito à tumulação régia. Com efeito, dos reis visigóticos guardou-se sempre, desde Rodrigo de Toledo (cap. 5) até à Crónica Geral de Espanha de 1344, a referência ao solene enterramento do rei Alarico debaixo do leito do rio Busento, com todas as suas armas e muitas riquezas e com os cadáveres dos seus escravos nesse dia sacrificados para o acompanharem na morte (cap. 81) ${ }^{6}$. Também se fala sempre do enterramento solene de Teodorico, morto na batalha dos Campos Cataláunicos contra Átila (cap. 87). Mas dos outros reis visigóticos diz-se apenas, geralmente, em que lugar morreram e quem lhes sucedeu, sem referir com foram enterrados. Como se ao narrador interessasse apenas a legitimidade da sucessão (sendo a indicação do lugar da morte do antecessor uma espécie de precisão destinada a garantir a autenticidade da informação sobre o facto) ${ }^{7}$.

Nas histórias dos reis asturianos e leoneses, a partir de Afonso II, surgem, porém, referências claras aos túmulos e à sua colocação em recintos sagrados especiais, como a Igreja de Oviedo e as de S. João e de Sto. Isidoro de León, que constituíram, assim, panteons régios onde se podia venerar a maioria dos restos dos reis do mesmo período. Além disso, as crónicas referem expressamente a preocupação de preservar os seus ossos contra violências e perturbações, como aconteceu durante as invasões de Almansor, quando Afonso $\mathrm{V}$ mandou reunir os ossos dos seus antepassados na igreja de S. João Baptista de León (Cr. 1344, cap. 412) ${ }^{8}$. Revela-se assim o propósito de exprimir a permanência da autoridade e de a ligar a um

\footnotetext{
${ }^{5}$ Não se encontram formulários nem rituais para morte dos reis no Liber ordinum moçárabe publicado por D. FÉROTIN em 1904, o que é confirmado pela recente edição de J. JANINI, Liber ordinum episcopal, Silos, 1991. 232).

${ }^{6}$ Ver também a Primera crónica general de Afonso X, cap. 408 (ed. Menéndez Pidal, p.

7Ver José Mattoso, 1993, p. 82-83.

8Ibid., p. 81.
} 
lugar sagrado que aparece aos olhos dos súbditos como o testemunho da ligação do poder terreno a um poder invisível, intocável, protegido directamente por Deus e que, por isso, garante a permanência da própria comunidade ${ }^{y}$.

A importância deste significado na historiografia castelhano-leonesa e portuguesa ressalta, por exemplo de na Crónica de 1344 aparecer um capítulo em que se expõe resumidamente a sucessão de todos os reis asturiano-leoneses até Bermudo III, e de aí se apontar sistematicamente o lugar do túmulo de cada um deles (cap. 250, p. 395-397) ${ }^{10}$. A lista dos reis que no mesmo capítulo se seguem, desde Fernando o Magno, fundador da dinastia navarra, até Afonso XI, já não os regista (ibid., pp. 398-399). Sinal de que a forma de exprimir a continuidade do poder se alterou. A Crónica de 1344, embora nada diga sobre esta alteração, permite detectá-la: tal como acontece com as obras historiográficas anteriores, a indicação do lugar dos túmulos passa a ter uma importância diferente para os cronistas que referem acontecimentos posteriores à morte de Fernando Magno. $\mathrm{O}$ acento deixa de se colocar na continuidade da prática tumular, expressa no facto de os reis anteriores terem sido normalmente enterrados em Cangas (informação provavelmente imaginária), em Oviedo e em León, primeiro na igreja de S. João Baptista e depois na de Sto. Isidoro, porque se verifica que os seguintes escolhem lugares diferentes uns dos outros, revelando assim o carácter individual e único que pretendem atribuir à sua própria memória.

Com efeito, embora no resumo da sucessão régia apresentado no cap. 250 da Crónica de 1344 não se apontem os lugares dos túmulos dos reis da dinastia navarra, a informação é dada nas notícias individuais dos

\footnotetext{
'Ibid, p. 81-85. Como fez notar R. HeRTz, 1990 (1917), p. 61, quando termina o período em que o cadáver se decompõe, durante o qual se praticam os rituais de integração do defunto na comunidade dos antepassados, "o elemento de repulsa e de desgosto acaba por ceder, dando lugar a uma confiança respeituosa na influència benéfica emanada do ossuário, que protege a aldeia contra a desgraça e ajuda os vivos nas suas empresas". Como é óbvio, atribuem-se poderes protectores especiais aos ossos dos chefes e grandes personagens. Sobre a relação entre centros políticos e lugares sagrados na Idade Média peninsular, ver M. GARCía PELAYO, 1981, p. 216, onde este autor, todaviá, não os relaciona com as sepulturas dos reis, mas com os lugares onde se guardavam as relíquias dos santos nacionais como $\mathrm{S}$. Tiago e Sto. Isidoro.

${ }^{10}$ Deve-se notar que não existe nenhum capítulo correspondente a este na Primera crónica general (ver ed. Menéndez Pidal, cap. 591-600, pp. 337-343), que até certo ponto Ihe serviu de modelo, o que talvez possa significar que o conde $\mathrm{D}$. Pedro atribuía aos túmulos régios maior significado político e ideológico do que Afonso $\mathrm{X}$.
} 
capítulos seguintes, quando se refere a morte de cada um" ${ }^{\prime \prime}$ O facto de se ter perdido a tradição de os reis de sepultarem todos no mesmo lugar não significa, portanto, uma menor importância atribuída ao túmulo, mas o carácter pessoal que a partir de então se passou a atribuir à memória funerária. Esta deixou de estar ligada a uma tradiçao colectiva, associada, por sinal à cidade onde a linhagem régia tinha o seu palácio mais importante, para se unir a um santuário da devoção pessoal de cada um dos seus membros (Sahagún ou as Huelgas de Burgos para Afonso VI, Afonso VIII e Henrique I) ou uma sé catedral com um carácter mais nacional, com a de Santiago de Compostela para os dois reis de Leão Fernando II e Afonso IX, a de Toledo para Afonso VII e a de Sevilha para Fernando III e Afonso X. Esta última foi certamente escolhida para lembrar o mais glorioso feito de Fernando III, a conquista de Sevilha aos mouros. A prática funerária já não acentuava a diluição da memória individual de cada um dos reis na ininterrupta sequência das gerações -o que os tornava instrumentos de um poder eterno e inabalável e colocava implicitamente $o$ acento na permanência do reino que eles serviam-, mas a maneira especial como cada rei assegurava a sua missão de exercer um poder que continuava a transcendê-lo mas que já não se justificava só pela permanência do reino. A mudança dinástica verificada com Fernando $o$ Magno e todas as alterações por ele introduzidas no governo dos seus reinos exprimem-se também na transformação dos costumes tumulares.

O hábito de referir nas crónicas os túmulos dos reis, nítido vestígio da importância ideológica que os contemporâneos lhes atribuíam como sinal visível não só da memória régia, e da permanência do poder, verifica-se também na historiografia portuguesa. Antes de mais na obra do Conde D. Pedro, que acabámos de mencionar a propósito dos reis asturianos, leoneses e castelhanos, mas também, e sem excepção alguma, nos textos do seu

\footnotetext{
"Fernando I em Sto. Isidoro de León (Cr. 1344, cap. 472, p. 348); A fonso VI em Sahagún (ibid., cap. 649, p. 199); Afonso VII em Sta. Maria de Toledo (ibid., cap. 729, p. 265); Fernando II de Leão, em Santiago de Compostela (cap. 745, p. 290); Afonso VIII nas Huelgas de Burgos (cap. 769, p. 341); Henrique I, também nas Huelgas de Burgos (cap. 780, p. 356); Afonso IX de Leão em Santiago de Compostela (cap. 794, p. 389); Fernando III na catedral de Sevilha (cap. 858, p. 496). Só não se indicam os lugares de sepultura de Sancho II (cap. 499. p. 389) e de Sancho III. A tradição mantém-se para os continuadores da Crónica de 1344: Para os reis de Castela Afonso X, em Sevilha (Ap. II, cap. 1, p. 513), Fernando IV em Granada (cap. 3, p. 516), e Henrique II na capela por ele mandada fazer na catedral de Toledo (cap. 14, p. 536). Só não se refere o túmulo de Sancho IV (p. 515) nem o de Pedro I (p. 533). O de Afonso XI viria provavelmente indicado na parte do mss. que se perdeu.
} 
continuador, ou seja, sem omitir sequer o túmulo de Sancho II de Portugal, morto no exílio, num lugar inacessível aos seus súbditos ${ }^{12}$. Este cuidado, mantém-se intacto no continuador da sua obra, que escrevia durante o reinado de Afonso $\mathrm{V}$, ou seja, um século mais tarde ${ }^{13}$. A mesma preocupação já se tinha então tornado uma regra característica da tradição historiográfica nacional, como se pode ver da maneira mais evidente na Crónica Breve do Arquivo Nacional, onde a biografia de cada rei se reduz a um esquema quase uniforme que menciona, de forma estereotipada, o nome do cônjuge e dos filhos, alguns breves feitos, a data da morte e o lugar do túmulo ${ }^{14}$, e também na Crónica de 1419, embora nesta o cuidado do redactor não seja tão aparente, porque essas informações aparecem distribuídas no texto a propósito de cada um dos reis. Também nesta Crónica não se omite nem uma só das notícias sobre o lugar onde cada um dos reis de Portugal está enterrado.

O cuidado com que os cronistas registam tal informação tem pressupostos importantes. O túmulo é como que um sinal de passagem, no sentido antropológico do termo, ou seja o testemunho de que o poder do rei, petrificado na estátua jacente, fora transmitido ao seu sucessor. Por outro lado, a imobilidade da figura não pretende apenas significar a morte do rei que ela representa, mas também a sacralidade estática e inalterável, do poder que ele exerceu. Os túmulos dos reis afirmam, portanto, na sua linguagem muda, mas eloquente, que o poder que dá consistência à comunidade, ao reino, é tão firme com as estátuas de pedra e tão inabalável que teve sempre sucessores que o transmitiram intacto uns aos outros numa cadeia ininterrupta. A sua sequência perdurou durante séculos e poderá continuar no futuro por tempo indefinido. Era preciso, portanto, registar, para cada um dos reis, a informação indispensável para que se percebesse a sequência de tais testemunhos, e para verificar, por meio dela, que a morte dos reis anteriores em nada alterava a permanência do poder régio que cada um deles havia exercido.

\footnotetext{
${ }^{12}$ Afonso Henriques e Sancho I em Sta. Cruz de Coimbra (cap. 714, p. 236; cap. 715, p. 237); Afonso II e Afonso III em Alcobaça (cap. 716 e 718, pp. 238 e 242); Sancho II em Toledo (cap. 717, p. 241), D. Dinis em Odivelas (cap. 725, p. 259).

${ }^{13} \mathrm{O}$ continuador da época de Afonso $\mathrm{V}$ também não omite nenhum rei: Afonso IV na Sé de Lisboa (Ap. III, cap. 1, p. 531), Pedro I em Alcobaça (p. 539), Fernando I em S. Francisco de Santarém (p. 541), João I, D. Duarte e o regente D. Pedro em Sta. Maria da Vitória (pp. 543 e 546).
}

${ }^{14}$ Publicada nos Portugaliae monumenta historica. Scriptores, pp. 22-23. 
Embora a Crónica de 1419 se insira claramente dentro destas concepçōes, possui algumas particularidades que merece a pena registar. Refiro-me a certas indicaçōes breves, mas onde se mostra o cuidado que alguns soberanos tiveram com a solenização dos seus monumentos funerários. Assim, Afonso II é sepultado «no muymento de Alcobaça na capela mór», ou seja no local mais importante da sua igreja abacial, à frente de toda a assembleia dos fiéis e junto ao altar onde se celebravam os mistérios divinos (cap. 10, p. 207); D. Dinis mandou fazer "sua hordenada sepultura" em Odivelas, no mosteiro de monjas cistercienses cuja oração considerava, decerto, especialmente agradável a Deus (cap. 46, p. 138); Afonso IV ficou no coro da Sé de Lisboa "em quamto se acabava sua sepultura. Porque ele tinha feyto seu solene testamemto [...], em que mamdou que na dita See ho sepultasem, na Capella mayor, homde ele e a Raynha, sua molher, hordenaram suas sepulturas" (Cap. 69, p. 372). Esta sucessão de notícias parece indicar um cuidado crescente na solenização da memória funerária enquanto memória individual. Com efeito, Afonso IV e sua mulher não se limitam a mandar fazer os seus túmulos; decidem também instituir capelas e mercearias, onde, como diz o cronista, "por suas louuadas memoryas e por gramde mereçymemto de suas almas amte Deos, com deuotas e samtas ymstituyções se mamtem e gouernam ymteyramemte, porque eles ambos pera sempre as dotarão de muytas remdas com vylas, e teras, e jurdições, como a todos he notoryo" (ibid.).

Como é evidente, esta prática historiográfica não fazia mais do que testemunhar uma prática social de forte sentido ideológico: não era tanto por meio da escrita que se exprimia a permanência inalterável do poder, apesar da morte de cada um dos seus detentores, mas sobretudo por meio dos próprios monumentos. A escolha do lugar e a forma do túmulo constituem, porém, sinais complementares desse sentido geral, com variações diacrónicas que convém agora examinar.

Quanto à escolha do lugar, para referirmos apenas os reis portugueses, é importante verificar que todos eles, com excepção de Afonso IV, preferem mosteiros de ordens monásticas ou conventos de mendicantes (conforme as épocas e as correntes religiosas dominantes no seu tempo), em cuja oração litúrgica confiavam e a cujos membros atribuíam a função de intermediários legítimos entre o poder divino e o poder temporal. Como veremos adiante, o rei considera-se representante de Deus na Terra e afirma que o seu poder vem de Deus. Como tal, só lho pode devolver a Ele próprio. Ė preciso, portanto, escolher um lugar sagrado especialmente apto 
a testemunhar esta devolução do poder a Deus e a sua aceitação pelo mesmo Deus. Daí a designação de lugares onde a disciplina, a pureza da vida religiosa, a solenidade da liturgia ou a prática de boas obras podiam ser interpretadas por todos como sinal autêntico e visível da presença divina: para Afonso Henriques e Sancho I, o mosteiro de Santa Cruz de Coimbra na época do seu esplendor inicial; para Afonso II, Afonso III e D. Pedro, a austera abadia de Alcobaça uma vez que os Cónegos Regrantes tinham entrado em decadência; para $D$. Dinis, o mosteiro de Odivelas, em cujas monjas cistercienses ele confiava especialmente; para D. Fernando, os franciscanos de Santarém, cuja pobreza devia ser particularmente estimada por Deus e pelos homens; para D. João I, os dominicanos da Batalha, que pela oração perpetuavam o sinal da legitimidade da nova dinastia sancionada por Deus com a vitória de Aljubarrota. Só Afonso IV escolhe uma sé catedral e não um mosteiro ou um convento, indicando assim que prefere uma vinculação por assim dizer institucional a uma autoridade religiosa que não representa Deus pelos mesmos critérios, mas pela legitimidade do poder sacramental recebido através da cadeia ininterrupta que a liga aos Apóstolos. A instituição de uma "capela" com oficiantes próprios e celebrações ordenadas pelo rei no seu testamento mostra que ele não confiava tanto nos sufrágios genéricos de uma comunidade monástica, mas que queria ser ele próprio a determinar os ofícios e a forma de os executar. Ou seja, o papel individual do rei perante a morte e a memória funerária vai-se acentuando sem cessar na Península Ibérica desde a época de Fernando o Magno.

Note-se que, apesar da dispersão dos túmulos e da divergência das devoções de cada rei, prevalece uma certa preocupação recorrente de exprimir a continuidade do poder: os três lugares sagrados preferentemente escolhidos são primeiro Santa Cruz de Coimbra, depois Alcobaça e finalmente a Batalha. Os reis que preferem estes mosteiros aos da sua devoção pessoal manifestam mais clara noção da continuidade do seu ministério e de que ele se exerce em função da comunidade do reino. Com efeito, o poeta Luís Henriques, que deixou no Cancioneiro Geral um poema à morte de D. João II, à semelhança dos antigos "prantos" medievais, e outro por ocasião da trasladação dos seus ossos para o mosteiro da Batalha, não deixa de notar a continuidade da memória régia que se exprime por meio da sepltura no mesmo local:

Ali vos trouxeram, u sam congregados todolos corpos de vosso abolorio, 
durante o mundo será mui notoreo

a grande memoria dos i sepultados (n. 367)

Este poema é um testemunho muito significativo da importância ideológica que em Portugal se atribuía aos túmulos dos reis.

Também é significativo observar que a tradição mais antiga, que acentua a continuidade e a sucessão, praticamente abandonada desde $D$. Dinis, e depois retomada por D. João I e os seus sucessores até D. Maruel, parece ter sido restaurada para exprimir a ideia de que a mudança dinástica fora confirmada por um sinal divino (a vitória de Aljubarrota), ao qual os reis portugueses deveriam manifestar depois uma especial fidelidade como expressão da legitimidade do poder, mas também, de novo, como sinal de um estreito vínculo entre o rei e o reino.

De qualquer maneira, todos estes túmulos se situam em lugares próximos da cidade em que o rei tinha o seu palácio principal: primeiro em Coimbra, e depois relativamente perto de Lisboa ou Santarém ou nestas mesmas cidades. A alternância da escolha entre um espaço urbano e um espaço rural não representa apenas a predominância, em cada época, de correntes culturais e religiosas que priviligiam a presença ao mundo ou a fuga do mundo, mas também, porventura, o desejo de distribuir pela área mais directamente ligada aos domínios régios os sinais do poder monárquico. Colocando os túmulos régios em Alcobaça ou na Batalha, como que a meio caminho entre o território do reino em que a soberania régia se podia exercer na sua total plenitude e aquele onde o rei tinha de a partilhar com os senhores, o monarca ostentava perante eles a sacralidade de um poder que assim reivindicava uma efectiva supremacia sobre todo o rei.

\section{O PODER DIVINO DO REI}

Não é fácil explicar em poucas palavras por que processo é que os reis da Idade Média ocidental consideravam que o seu poder lhes tinha sido conferido por Deus. Não tentaremos, porém, debater esta questão cujo esclarecimento não é indispensável para o problema que nos ocupa aqui. $\mathrm{O}$ facto é que, a partir de certa data, se descrevem frequentemente mortes exemplares de reis, e se apresenta muitas vezes um discurso ou algumas frases em que eles declaram devolver a Deus o poder que dele haviam recebido. Embora o contexto em que tal se verifica seja o da cena edificante, 
em que se coroa uma biografia modelar com o relato de uma morte igualmente modelar, a análise destes relatos revela de facto uma concepção do poder que o torna uma realidade independente da morte. Com efeito, o poder régio aparece como a emanação da soberania divina, ou seja, portanto, com o carácter de uma autoridade eterna e sagrada. O poder régio não pode, pois, morrer com a morte do seu detentor terrestre.

O poder vem de Deus e, por isso, é-lhe restituído sem condições. Nos textos que estamos a examinar aparecem, porém, os primeiros sinais de que o rei moribundo ao entregá-lo ao Criador, pensa desde logo naquele que lhe há-de suceder. Trata-se, em todo o caso, de um fenómeno bastante tardio, em aparente oposição com a precocidade das conhecidíssimas práticas destinadas a assegurar a sucessão em favor de um filho, em princípio o primogénito, as quais se encontram já, como se sabe, durante a época visigótica. A resistência das velhas concepções que faziam depender a sucessão da eleição e não da hereditariedade explica, decerto, o carácter tardio de tal fenómeno. Com efeito, encontram-se nas crónicas peninsulares muitos vestígios de referências expressas à eleição, pelo menos sob a forma de aceitação e aclamação do sucessor pelos súbditos, até pelo menos à coroação de Fernando III em $1230^{15}$. Daí, talvez, o carácter tardio da referência à sucessão associada à entrega do poder régio a Deus por ocasião da morte de qualquer soberano.

Vejamos, porém, os textos em que se refere esta entrega. $\mathrm{O}$ mais antigo dos que encontrei pertence a Rodrigo de Toledo, que escreve no princípio da década de 1240 . É posto na boca de Fernando I, que ao morrer diz: "Tua est potentia, tuum est regnum, Domine, tu es super omnes reges, tuo imperio omnia sunt subiecta: quod te donante accepi, restituo tibi regnum, tantum animam meam in aeterna luce iubeas collocari" (VI, cap. 13, ed. Lorenzana, p. 128). O tom é, como se vê, o do acto de piedade. O rei age como um fiel cristão que reconhece que deve o poder a Deus e lho restitui, pedindo apenas, em troca, e em virtude da inteira misericórdia divina, a salvação eterna. Deve-se interpretar este passo a partir do contexto

\footnotetext{
${ }^{15}$ Ver, por exemplo RodRIGO DE TOLEDO, De rebus Hispaniae, IX, cap. 5 (ed. Lorenzana, p. 196); Primera Crónica General, cap. 1028 (ed. Menéndez Pidal, p. 713); Crónica de 1344, cap. 778 (ed. Cintra, IV, pp. 352-353). Sobre a persistência das práticas electivas, ao menos sob a forma de aclamação, ver C. SÁNCHEZ ALBORNOZ, La sucessión al trono en los reinos de León y Castilla, in ID., Estudios sobre las instituciones medievales españolas, México, Universidad Nacional Autónoma, 1965, pp. 639-704; Marcelo CaETANO, História do Direito português, Lisboa, ed. Verbo, 1981, pp. 211-212, 441-452, 462, 468-469.
} 
de uma obra em que o autor, embora particularmente fiel à monarquia e à pessoa de Fernando III, pretende significar que a origem do sucesso temporal de qualquer rei está no seu especial respeito pelas autoridades eclesiásticas.

Como se sabe é em Rodrigo de Toledo que Afonso X se inspira para a sua Primera crónica general. Não admira, portanto que o mesmo texto inspire nitidamente o do rei Sábio acerca do mesmo acontecimento: "Sennor tuyo es el poder et tuyo es el regno, et tu eres sobre todos los reys et sobre todas las yentes et todas las cosas son a tu mandamiento. Pues Sennor, tornote yo agora el regno que me tu diste, mas pidote mercet que la mi alma sea puesta en la luz que non a fin" (cap. 813, ed. Menendez Pidal, p. 494).

Note-se que em nenhum destes discursos se encontra qualquer menção ao sucessor. Veja-se agora como o Conde D. Pedro transmite a mesma situação na Crónica de 1344: "Senhor Deus todo poderoso, que reges o mundo per teu grande poder e es rei e senhor sobre os reys da terra e teu he o reyno e imperio sobre todollos hom ees, e tu das vida a toda a cousa vivente e eyxalças em honrra aos que te praz! E tu, Senhor, deste a $\mathrm{m} \sim \mathrm{y}$ reynos e senhorio pera reger e poseste em grande honrra a minha fazenda e eixalçaste o meu estado [...]. Rogote, meu senhor Deus, que recebas os reynos que me deste $e$ os des a reger a quem for tua merçee pera teu serviço" (cap. 472, ed. Cintra IV, p. 347). Como se vê, não se pode deixar de considerar significativa a última frase desta passagem inspirada na obra anterior.

A intenção fortemente ideológica da obra de Rodrigo de Toledo explica que nela se encontre também um capítulo acerca das virtudes do rei, sobretudo da fidelidade, a propósito de Fernando II de Leão (note-se o relevo que o Autor queria dar aos reis deste nome, uma vez que escrevia para Fernando III). Aí se exprime claramente o mesmo princípio da origem divina do poder régio, mas para mostrar expressamente como os reis se devem sujeitar a Deus, ou seja, às autoridades eclesiásticas: "[Deus] dedit illi certamen ut vinceret, et sciret quoniam omnipotens regit reges, et per eum principes tenent terram" (VII, cap. 18, ed. Lorenzana, p. 163). Este passo doutrinal, porém, não tem qualquer correspondência com as obras que lhe sucederam ou seja com a Primera crónica general, a Crónica de 1344 e outras. Quer dizer que estas, embora menos sensíveis a princípios teóricos, não deixam, por isso, de relatar factos com pressupostos idênticos.

Mas se o De rebus Hispaniae não tem, neste caso, paralelo algum com as outras duas obras, acontece algo de semelhante na Crónica de 1344 
com o relato da morte de Afonso VI de Leão e Castela, onde aparece um discurso do moribundo que não se encontra em Rodrigo de Toledo nem em Afonso X (respectivamente VI, cap. 34 e cap. 964). Com efeito, o Conde D. Pedro insere na sua obra um discurso nitidamente inspirado no de Fernando I, que comentei há pouco, e que apresenta também uma referência ao sucessor: "Oo grande Deus de piadade [...] Senhor teus son os reinos e o enperio e tu es rey dos reys e senhor dos senhores. Tu das os reynos a quem he tua merçee e hos tiras quando te praz. Senhor desteme reynos a mãdar e eu nõ te servi cõ elles commo devera $\mathrm{n} \sim \mathrm{e}$ guardey os dereitos ao teu poboo asi commo era teudo de fazer [...] Eu t'encomendo os reynos de Castella e de Leõ que os ajas en tua guarda $e$ os provejas de tal pastor que seja hõrra de tua santa fee (cap. 694, ed. Cintra, IV, p. 198). Note-se que aqui, tal como no discurso anterior, o rei pede a Deus um sucessor digno do reino.

Acerca da morte de Fernando III, que obviamente não podia ser relatada por Rodrigo de Toledo, aparece um texto bastante simples na Primera crónica general. Também aqui há um pequeno discurso do moribundo: "Sennor disteme regno que non auia [...] Sennor, gracias te do, et rendote et entregote el regno, que me diste con aquel aprouechamiento que yo pud fazer, et ofrezcote la mi alma" (cap. 1133, ed. Menéndez Pidal, p. 773). O relato correspondente do Conde D. Pedro é bastante semelhante mas sublinha a realeza de Cristo: "Senhor Jhesu Cristo, rey dos reys e senhor de toda a terra, desteme reyno a mandar que eu nõ avia [...] E hora, Senhor, te entrego o reyno que me deste con aquel aproveytamento que hy pude fazer e peçote por mercee que recebas minha alma enna tua gloria" (cap. 857, ec. Cintra, IV, p. 495). Como se vê nem um nem outro falam de sucessão mas ambos haviam mencionado antes as palavras com que Fernando III havia encomendado o reino a seu filho Afonso $X$ : "Se o souberes guardar no mesmo estado em que eu o deixei, serás tão bom rei como eu; se mais ganhares serás melhor do que eu; mas se o minguares não serás tão bom como eu" (cap. 1132, pp. 772-773; cap. 856, p. 494).

Parece que devemos interpretar estes dados como um indício de que a ideia da transmissão do poder a Deus estava cada vez mais ligada com a da transmissão ao sucessor. Inicialmente havia apenas a ideia de restituir a Deus o que dele tinha sido recebido: assim o supōem Rodrigo de Toledo c. de 1240 e Afonso X c. de 1280 a propósito de Fernando o Magno. Depois esta ideia não impede Afonso $\mathrm{X}$ de, pela mesma época, referir como exemplares as palavras em que Fernando III encomenda o seu reino ao filho. 
Mais tarde, pouco depois de 1340 , o conde D. Pedro pensa que a restituição do poder a Deus é provisória e que Deus o entregará imediatamente ao sucessor, que obviamente será o que a natureza deu ao rei anterior, ou seja o seu filho primogénito ${ }^{16}$. A ideia de que a sucessão não dependia apenas da transmissão hereditária, mas também da eleição ou pelo menos da aceitação dos súbditos, impediu durante séculos de associar a devolução do poder a Deus com a sucessão. $O$ respeito pela infinita liberdade divina, cue não podia de modo algum sujeitar-se à vontade dos homens, também impedia de associar uma coisa e a outra. $O$ poder era exercido pelo rei mas não era propriedade sua. Mas o costume, cada vez mais uniforme, de transmitir o poder ao herdeiro principal acaba por fazer encontrar uma forma de conciliar as duas ideias. O que, de qualquer modo, está presente na mente de todos os autores é que o poder tem a sua fonte em Deus porque é eterno e por isso não pode morrer com o seu detentor.

Estas ideias encontram-se ainda no segundo quartel do século XV, por exemplo quando Fernão Lopes escreve a Crónica de D. Fernando. Quando o rei sentiu a morte, pediu os sacramentos. Ao perguntar-lhe o celebrante se cria nos artigos da fé, respondeu: "Todo esso creo come fiell christaão, e creo mais que elle me deu estes rregnos pera os manteer em dereito e justiça, e eu por meus pecados o fiz em tall guisa que lhe darei d'elles mui maao conto» (cap. 172, ed. Macchi, p. 592). Como se vê, o cronista respeita a tradição de o rei reconhecer à hora da morte que o seu poder vem de Deus e implicitamente de lhe restituir o que dele recebera. $O$ cronista nada diz acerca do sucessor, provavelmente porque tinha acabado de explicar o que ficara estabelecido nas pazes de Salvaterra.

Mas a inclusão de uma cena edificante deste género numa crónica régia não se torna um preceito obrigatório: não aparece na Crónica de $D$. Pedro I do mesmo autor (ver o cap. 27) e deixa depois de figurar nas crónicas portuguesas das décadas seguintes. De facto, mesmo quando estas obras pretendem descrever mortes exemplares, como acontece com Rui de Pina acerca da de D. João I, ou com Garcia de Resende acerca da de D. João II $^{17}$, verifica-se aí um total silêncio acerca da origem divina do poder e da obrigação de o devolver a Deus no momento a morte do seu detentor.

\footnotetext{
${ }^{16}$ Sobre a sucessāo automática em favor do primogénito, como "juizo de Deus", ver mais adiante a nota 21 .

${ }^{17}$ RUI DE PINA, Chronica do Senhor rey D. Duarte, cap. I (ed. Lopes de Almeida, p. 489); GarCia de ReSEnde, Crónica de D. João II, cap. $211-212$ (ed. 1798, pp. 280-285).
} 
Este silêncio não quer dizer que tenha desaparecido a ideia da permanência do poder régio. $O$ que provavelmente acontece é que a noção de sucessão hereditária que garante a transmissão imediata a um novo rei depois da morte do anterior, dispensa o recurso à divindade. A laicização crescente das ideias políticas que estava em curso desde o princípio do século XIV tornava as expressões do Conde D. Pedro e de Fernão Lopes talvez um tanto anacrónicas na própria época em que eram escritas quando as comparamos com as ideias que então passaram a dominar na Europa. Em Leão e Castela, pelo contrário, a concepção teológica da realeza que considera o poder de origem divina, que atribui ao rei o papel de vigário de Deus e que concebe o reino de Deus como um arquétipo político aparece insistentemente em vários autores a favor dos soberanos Trastámaras e mantém-se até ao princípio do século $X V I^{18}$. É verdade que além-Pirinéus vai prevalecendo, desde Marsílio de Pádua, a ideia de que o rei recebe directamente de Deus a sua autoridade, superando-se assim as ideias teocráticas dos séculos anteriores, que declaravam a superioridade do poder espiritual (exercido por intermédio da autoridade eclesiástica). Aí, portanto, o problema da continuidade do poder temporal suscita numerosas e complexas teorias jurídicas que elaboram o conceito de pessoa colectiva, permanente para além da morte dos seus membros e subsistente no aevum, ou seja numa coordenada temporal entre a eternidade e o devir histórico. $\mathrm{O}$ seu carácter político (ou seja, não necessariamente religioso ou espiritual) permite que a origem divina das suas prerrogativas não dependa da intervenção das autoridades eclesiásticas, e por isso supera as ásperas controvérsias em torno da teocracia ${ }^{19}$. Na Península, porém, parece verificar-se, talvez por a oposição entre poder secular e poder espiritual ser menor do que além-Pirinéus, que o conceito de continuidade do poder não é justificado por juristas e filósofos nos seus respectivos campos do saber, mas por cléricos e moralistas, a partir de ideias teológicas e morais ${ }^{20}$. Além disso, como vemos em Rodrigo de Toledo, na Primera crónica general e no

${ }^{18}$ J. M. NIETO SORIA, 1988, pp. 49-59.

${ }^{19}$ Estas ideias foram abundante e pormenorizadamente expostas por KANTOROWICZ na sua conhecida obra Os dois corpos do rei, 1985 (1957). Aí se vế que o problema da continuidade do poder deu origem a teorias extremamente elaboradas e complexas, que, segundo parece, não tiveram grande expressão na Península Ibérica.

${ }^{20} \mathrm{E}$ o que parece deduzir-se do conjunto de autores citados e comentados por NIETO SORIA, 1988, pp. 255-259. 
Conde D. Pedro, o acto de se considerar que o poder do rei vem directamente de Deus, sem o intermediário da autoridade eclesiástica, como pressupõem os textos citados, não significa que o rei se possa prevalecer de uma autoridade de que não tem de dar contas a ninguém. Pelo contrário, isso é uma razão para se comportar como fiel cristão e para cumprir exemplarmente todos os seus deveres religiosos. Seja como for, para autores que exprimem ideias correntes e não reflexões teológicas, como os cronistas que estamos a comentar, o conceito de devolução do poder régio a Deus, introduzido, ao que parece, por Rodrigo de Toledo, vem a desaparecer face à prevalência do princípio ou da prática da sucessão automática em favor do herdeiro natural, que já havia sido expressa e oficialmente afirmado na França e na Inglaterra na década de $1270^{21}$.

A ideia da continuidade do poder régio, prevalecente, em Portugal, até meados do século $\mathrm{XV}$, por intermédio principalmente do conceito de origem divina do poder, permitiu encarar, aparentemente sem grandes angústias colectivas, o momento da sucessão. De facto a transmissão do poder tinha-se dado, historicamente falando, quase sem convulsões, sob a forma de transmissão hereditária em favor do primogénito. As graves desordens que se sucederam à morte de D. Fernando foram superadas, ideologicamente falando, pela vitória de Aljubarrota; mas a partir desse momento o conceito de sucessão legítima voltou a prevalecer sem dificuldade de maior, e sem ser necessário desenvolver teorias especiais acerca da perpetuidade do poder. A julgar pelas descrições das exéquias reais que os historiadores da dinastia de Avis nos deixaram, as manifestações da continuidade revestiram desde então a forma de acentuada solenização das cerimónias mortuárias, transformadas em grande espectáculo de luto que passou a desenrolar-se no imponente palco da Batalha. As crónicas de Rui de Pina e de Garcia de Resende descrevem longa e pormenorizadamente as pompas fúnebres dos reis, sobretudo de D. João I e de D. João II, demonstrando claramente que, por meior delas, os sucessores destes monarcas, ou os membros da corte que inspiraram a sua celebração, não se pouparam a esforços para que todo o reino guardasse uma recordação

\footnotetext{
${ }^{21}$ E. H. KANTOROWICZ, 1985 (1957), pp. 311-315. Como este autor mostra, o conceito de sucessāo automática impōe-se por intermédio da ideia de que o nascimento de um herdeiro correspondia a um verdadeiro "juízo de Deus", que assim sancionava indirectamente a sucessão: pp. 315-316.
} 
inolvidável de tais actos em virtude da sua riqueza esmagadora ${ }^{22}$. A grandiosidade e a expressividade do espectáculo funerário presidido pelo sucessor, passou então a desempenhar um papel primordial, como forma privilegiada de afirmar que a morte do rei não significava a morte do poder; a morte do rei tornava-se, pelo contrário, no momento da sua demonstração mais inesquecível.

\section{O LuTO CósMico}

A progressiva automatização da sucessão hereditária pode ter tido como efeito o desaparecimento, ou pelo menos a atenuação de antigos e profundos temores colectivos suscitados pela morte dos chefes. É verdade que não deve ter sido simples nem linear o processo pelo qual os monarcas se apropriaram em seu favor de crenças e rituais vindos de épocas muito longínquas e que se compreendem mais facilmente em comunidades rudimentares intimamente dependentes dos seus chefes. O que importa, porém, é que estas manifestações, que por vezes assumiam aspectos verdadeiramente irracionais, se encontram de forma recorrente na Península Ibérica pelo menos até ao século XVI, sem que se possa saber se partiam espontâneamente de crenças populares ou se nasciam de autores eruditos que as atribuíam ao povo para de alguma maneira inculcarem a ideia de que os hiatos do poder régio traziam consequências terríveis para todo o reino.

A verdade é que, a partir do século XIII, encontramos em vários textos algumas referências àquilo a que se poderia chamar um "luto cósmico" por ocasião da morte de certos reis. O seu sentido antropológico é bem claro: o rei, como sustentáculo do poder, é essencial para a ordem do mundo. A sua morte é, por isso mesmo, especialmente perturbadora, não só para os parentes mas para todo o reino. As convulsões sociais a que pode dar lugar têm um paralelo nas desordens que se revelam no mundo físico, nos astros, no aparecimento de monstros ou nas perturbações metereológicas. É o luto da natureza. O luto dos homens serve, de alguma maneira, para restabelecer a ordem. Por isso o que os súbditos então praticam torna-se

\footnotetext{
"2Veja-se uma cómoda selecção de textos de Fr. João Álvares, Zurara, Rui de Pina, Garcia de Resende, Damião de Gois, etc., em Saúl A. Gomes, 1994, e o cuidadoso comentário do mesmo Autor. Acerca de vários destes textos e de outros do Cancioneiro geral, ver também a interpretação de L. Adão da Fonseca, 1993.
} 
tanto mais intenso quanto mais estimado era o rei e os sinais da perturbação cósmica tanto mais aterradores quanto mais crítica é a situação em que o reino se encontra. Os autores que descrevem o luto apresentam-no sempre como partilhado unanimemente por todo o povo; por vezes associam-no à agitação da natureza, dos elementos ou dos astros. Vejamos que informações deste género podémos encontrar.

Teoricamente estes testemunhos deviam ser mais claros e abundantes em épocas mais próximas de costumes primitivos ${ }^{23}$, especialmente sensíveis ao paralelismo entre a ordem cósmica e a ordem social; ou seja, no princípio da Idade Média. Todavia, os cronistas da época asturiana e os do século XI e XII são talvez demasiado formais e concisos para desenvolverem temas como este. A sua concepção de História não os convidava a registarem costumes ritualizados. Existiam, decerto, mas não temos sobre eles nenhuma informação $0^{24}$. Encontramo-los pela primeira vez, e por sinal sob uma forma muito intensa, na Crónica latina dos reis de Castela, obra redigida c. 1225 (com um acrescento de c. 1236/7) que, segundo parece, se deve atribuir a João, bispo de Osma e chanceler do rei Fernando III. Com efeito, ao descrever a morte de Afonso VIII de Castela, o autor reproduz uma espécie de pequeno poema constituído por uma fórmula de maldição daquela noite e por uma lamentação pela perda daquele que simbolizava no reino a beleza, o bem e o vigor. A perda do rei era, para Castela, causa de dor perpétua até ao fim do mundo. As hipérboles usadas dão à morte um acento dramático. Transferem o luto das pessoas para o próprio reino e até para a própria natareza: "De todas as partes acorrem homens das cidades e nobres, ao terem conhecimento da morte de tão grande senhor. Vendo que ficavam privados de tão grande rei, entregavam-se ao espanto, chorando interiormente com grande angústia do espírito. Todas as mulheres rompiam em lamentações e os homens deitavam pó na cabeça, cingiam cilícios e vestiam-se de sacos. Toda a glória da Castela se mudou de repente e como que num fechar de olhos" (ed. L. Charlo Bréa, p. 41).

Esta dramática descrição do luto nacional pela morte de Afonso VIII surge no texto do cronista como preâmbulo a uma época de prolongadas lutas e perturbações, como se a morte do rei fosse ela própria a manifestação

\footnotetext{
23Ver os textos de R. Hertz e de L.-V. Thomas citados na nota 2.

${ }^{24}$ As fontes litúrgicas também não permitem superar esta lacuna, porque, como vimos na nota 5 não apresentam nenhum ritual específico para a morte dos reis.
} 
de uma desordem cósmica. Pode-se encontrar um relato de certo modo comparável no De rebus Hispaniae de Rodrigo de Toledo, que escreve pouco tempo depois de João de Osma e deve ter conhecido a sua obra, mas assume uma atitude mais confiante na descrição dos mesmos acontecimentos. No seu relato refere-se também, mas em termos menos dramáticos, à perturbação causada pela morte do mesmo rei: "Assim, a notícia da sua morte atingiu o coração de todos como se fossem feridos inesperadamente pelo golpe de uma seta. Assim, a valentia, a generosidade, a cortesia, a sabedoria e a modéstia que ele defendia desde a infância pareciam agora, depois da sua morte, sepultadas com ele. Todas estas virtudes desapareceram, não só no seu reino, mas noutras partes da Hispânia, dissipada a disciplina e desencadeada a licença; não mais se cultivaram por se terem perdido os tesouros da vergonha [...]. Assim como em vida tinha enchido o reino de virtudes, assim com a sua morte toda a Hispânia, e até todo o mundo, desfaleceu, lavado em lágrimas" (VIII, cap. 15, ed. Lorenzana, p. 92).

Verificamos assim que, para o arcebispo de Toledo, a morte do rei representava uma anomalia que abalava mais o mundo dos homens do que a natureza. $O$ rei aparece como o sustentáculo da ordem social e da virtude de todo o reino, ou mesmo de toda a Hispânia: a sua morte física acarretava o desaparecimento das próprias virtudes morais que ele defendia e praticava. A ligação entre o rei e o reino é de tão íntima que a morte de um traz consigo a desagregação do outro, enquanto corpo orgânico e coerente. Há um perfeito paralelismo entre o corpo do rei e o corpo do reino. A conexão entre eles é mais íntima que a instaurada pela ordem simbólica. Ou melhor, a morte que atinge $\rho$ rei, como símbolo vivo do corpo do reino, atinge também, não de forma simbólica, mas realmente, o princípio que sustenta a coesão do reino. A ordem metafórica repercute-se efectivamente sobre a ordem real.

Não é este, porém, o único vestígio de uma interpretação da morte régia como desencadeadora de perturbações que abalam todo o reino. $\mathrm{O}$ mesmo Rodrigo de Toledo também descreve a morte do rei Afonso VI como a primeira das calamidades que desde então se seguiram e assolaram durante vários anos os reinos de Leão e Castela. $\mathrm{O}$ rei estava doente havia bastante tempo. Depois, "como Deus omnipotente aceitara as suas acções", diz o cronista, "quis anunciar a sua morte por um prognóstico especial". Estando ele na cidade de León, para celebrar a festa da natividade de $S$. João Baptista, começou ao meio-dia a brotar água das pedras dos degraus do altar 
da igreja de Sto. Isidoro e continuou a correr durante três dias. Ao terceiro dia, os bispos de Leão e de Oviedo, as duas capitais do reino leonês, que por essa altura estavam na cidade, foram processionalmente da catedral até à igreja, com todo o clero e o povo, celebraram missa e beberam da água sem saberem o que ela anunciava. Quando ouviram a notícia da morte do rei, logo souberam que estava eminente o luto e a tribulação da Hispânia tornada orfã. Por isso até as pedras choravam. O comentário do historiador toma então a forma de um pranto funerário: o rei, diz ele, "deixou o seu povo em luto e a pátria em perigo, trouxe a alegria aos inimigos e a lamentação aos pobres, desencadeou os suspiros dos religiosos. Quando ele morreu, o ladrão saíu à luz do dia, o predador afoitou-se, o pobre teve de se esconder e o clero de se calar; o camponês de chorar, o inimigo cresceu, a vitória fugiu, a derrota cresceu, a espada feriu os pacíficos e a pátria preparou-se para 0 extermínio, porque cada qual fazia o que queria" (VI, cap. 34). De novo se acentua aqui a perturbação social; mas o prognóstico das pedras que choram revela também a crença numa perturbação cósmica. A natureza associa-se ao luto não só pela morte do rei, mas também porque ela abala todo o reino. Desaparecido o soberano, o reino desagrega-se enquanto corpo. $O$ rei era verdadeiramente o sustentáculo da ordem social no território que lhe tinha sido confiado por Deus para governar.

Poder-se-ia pensar que estes testemunhos se justificam em virtude das convulsões que historicamente se verificaram depois da morte de Afonso VI e da de Afonso VIII. A uma seguiram-se os conturbados anos do governo de Afonso I de Aragão e de D. Urraca; e a outra, as lutas entre as famílias nobres que queriam tutelar o rei Henrique I durante a sua menoridade e que estendiam a desordem a toda a parte. Mas se os comparamos, por um lado, com as manifestações de luto e com as crenças de muitos povos primitivos descritas pelos etnólogos ${ }^{25}$, e, por outro, com os prantos fúnebres dos trovadores galego-portugueses, por ocasião da morte de Fernando III de Castela, da rainha D. Beatriz da Suábia, do rei D. Dinis e de outros membros da alta nobreza, vamos encontrar hipérboles semelhantes e alusões expressas ao luto de toda a natureza. Aquilo que foi considerado por historiadores da literatura como um defeito de gosto pelo seu carácter formal e excessivo torna-se assim uma manifestação obrigatória do luto colectivo e a expressão de uma dramatização catártica, para esconjurar as ameaças de

\footnotetext{
${ }^{25}$ Ver as obras de R. Hertz e de L.-V. Thomas citadas na nota 2.
} 
perturbações sociais ou mesmo de catástrofes naturais ${ }^{20}$. Os prantos pela morte dos reis representam crenças profundamente arreigadas e inserem-se em processos de ritualização do luto para que ele atinja o seu pleno efeito, que é o de restaurar a ordem do mundo.

Face a estes testemunhos, não pode deixar de se considerar como verdadeiramente exemplar o que a Primera crónica general diz acerca da morte do rei Espan, do qual procede miticamente o nome da Espanha, e que. para o autor. desempenha as funções de rei fundador e de personagem arquetípica em relação com os destinos da Ibéria. Este sobrinho de Hércules, que lhe sucedeu como senhor das Espanhas, mas que foi o seu primeiro rei, tendo fundado a cidade de Cádiz, morreu vinte anos depois da segunda destruição de Troia "e fue mucho llannido de los espannoles, assi que algunos y ouo ques mataron por el y otros que numqua quisieron reyr ni auer alegria ninguna ni uestir panno de color" (cap. 10, ed. Menéndez Pidal, p. 12). O luto é, portanto, inaudito, ou melhor, tão mítico, tão exemplar, como o rei que ele chorava. É, de facto, mítico, porque leva a excessos como o suicídio, a total renúncia ao riso e à alegria, o abandono completo do vestuário de cor. A morte do rei afecta para sempre a vida de alguns súbditos, como se se tratasse de uma perda irreparável. Como todos os arquétipos, as suas reproduções no tempo padecem de algum defeito. O luto pela morte dos reis terrenos não terá as mesmas dimensões extremas, mas encontra neste luto primordial o seu modelo exemplar. Pouco importa que a Igreja tenha tantas vezes levantado a sua voz contra tais excessos, como contrários à crença dos cristãos na vida eterna. As pessoas enlutadas, habituadas a costumes profundamente arreigados desde os tempos mais longínquos, reclamavam expressões dramáticas e espectaculares de "doo", porque sem elas dificilmente podiam acreditar que a ordem do mundo, perturbada pela morte, podesse ser de facto restaurada. A descrição de prantos de grande intensidade aparece, portanto, aqui, e em muitas outros relatos de exéquias, como de actos dignos da maior admiração e de todo o louvor, apesar das censuras da Igreja. São a reacção necessária e adequada à morte de grandes reis. Só a sua intensidade pode reparar a agressão que

\footnotetext{
${ }^{26}$ Tratámos deste tema em artigo de homenagam a G. TAVANI $O$ pranto fünebre na poesia trovadoresca galego-portuguesa, a publicar no respectivo volume organizado por Ettore FinazziAgro e na colectânea $O$ reino dos mortos na Idade Média peninsular, no prelo, a publicar pela Ed. João Sá da Costa.
} 
a morte de reis tão virtuosos e tão poderosos representa para o reino que deles dependia.

O carácter exemplar do luto pela morte de Espam foi bem sublinhado pelo nosso Conde $\mathrm{D}$. Pedro, não apenas porque o descreve por meio de palavras semelhantes (acrescentando que alguns juraram nunca mais comer carne: cap. 11, ed. Cintra, vol. II, p. 34), mas sobretudo porque vê expressamente nele o modêlo do luto feito por morte de Fernando III, o último rei da sua Crónica: "Quem poderia dizer verdadeiramente $[\ldots]$ o muy gram planto e doo que foy feito por el rey dom Fernãdo por todollos reynos de Castela e Leon?! [...] E bem assy como no tempo da morte de Espam, aquel bõo rey que pobrou e afortelegou Spanha, foi feito gram doo e planto per toda a terra, assi foy feito gram doo por el rey dom Fernando, en guisa que $\mathrm{n} \sim \mathrm{uca}$ os poboos dos reynos de Castella e de Leon tal planto fezeron por nenh uu rey que lhes ante nem despois morresse. Ca ben assi como Espam pobrou Espanha de gentes de Grecia e doutras muytas partes, bem assi este muy nobre rey dom Fernando pobrou grande parte d'Espanha, tirando della os mouros e dandoa aos cristãaos" (cap. 858, ed. Cintra, vol. IV, p. 496).

Esta comparação dispensa o Conde de descrever com mais pormenores o luto pelo mesmo rei, ao contrário do que fizera antes dele a Primera crónica general. Merece a pena transcrever este passo, apesar da sua extensão, para mostrar como a intensidade do luto devia ser proporcional à exemplaridade do rei: "Qui podria dezir nin contar la marauilla de los grandes llantos que por este sancto et noble et bienauenturado rey don Fernando fueron fechos por Seuilla, o el su finamiento fue et do el su cuerpo yaze, et por todos los reynos de Castiella et de Leon? Et quien uio tanta duenna de alta guisa et tanta donzella andar descabennadas et rascadas, ronpiendo las fazes et tornandolas en sangre et en carne biua? Quien vio tanto infante, tanto rico omne, tanto infançon, tanto cauallero, tanto omne de prestar andando baladrando, dando bozes, mesando sus cabellos et ronpiendo las fruentes et faziendo en sy fuertes cruezas? Las marauillas de los llantos que las gentes de la çiptad fazien, non es omne que lo podiese contar. Yueues fue por noche aquel doloroso dia en que este sancto rey [...] dexo la uida deste mundo et se fue para la perdurable o reyna aquel cuyo seruidor fue, quel touo y buen reyno apareiado" (cap. 1134, ed. Menéndez Pidal, p. 773). E depois de descrever as cerimónias litúrgicas das exéquias, acrescenta uma referência aos grandes prantos que o rei de Granada mandou também fazer aos seus súbditos, e ao sentimento de dor que em todos os 
reinos cristãos igualmente se manifestou quando souberam da sua morte. Como se vê, não há nesta descrição qualquer censura aos excessos praticados no luto, muito pelo contrário: a morte de um rei tão virtuoso não poderia deixar de suscitar tais manifestações. Elas eram a prova das suas virtudes e de como a sua morte era irreparável.

Logo a seguir a Primera crónica menciona uma grande mercê que Deus fez a toda a Espanha no tempo daquele rei, por nunca então ter havido nela nenhum «ano mau». Esta referência liga indirectamente o luto a uma real idade cósmica. Parece entender-se que depois disso houve anos maus. De facto sabe-se que o princípio do reinado de Afonso $\mathrm{X}$, durante os anos de 1255 a 1262 , foi marcado por catástrofes deste género ${ }^{27}$. $O$ redactor deste passo, que sem dúvida alguma os conheceu, associava, pois, instintivamente, o luto pela morte de Fernando III com as intempéries metereológicas que traziam a fome e a desolação.

É interessante verificar, dada a semelhança entre a matéria histórica da Crónica de 1344 e a da Primera crónica general, que aquela parece conceder maior importância ao luto do que esta. De facto, examinando a propósito de que reis se menciona ali o pranto por sua morte, verifica-se que se trata de personagens a que é atribuída uma importância especial em virtude do significado histórico e valorativo que o autor lhes atribuía. Além do luto pelo rei Espam, que já comentámos, o Conde refere-se ao que se fez pelos reis Afonso II de Leão, o restaurador dos costumes góticos; por Ramiro II, que ele relaciona especialmente com a Reconquista em Portugal; por Fernando I, o conquistador de Coimbra e iniciador da dinastia navarra; por Sancho II, o heroi do Cantar do cerco de Zamora; por Afonso VI, o conquistador de Toledo; e por Fernando III, o conquistador de Sevilha (cap. $249,159,472,499,694,858$ ). Ora o texto da Ṕrimera crónica general, em que o Conde se inspirou e que em grande parte vai seguindo, não menciona qualquer pranto a favor de nenhum destes reiș, excepto os dois último, para um de forma muito concisa, e para o outro com os grandes pormenores que já comentámos. Devemos certamente concluir daqui que o luto está intimamente associado à importância histórica de um rei e que sublinha a necessidade de cultivar a sua memória. É mais uma particularidade da Crónica de 1344 que revela a importância que o seu autor atribuía aos rituais

\footnotetext{
${ }^{27}$ Santiago AGUADÉ NiETO, En los orígenes de una coyuntura depresiva: la crisis agraria de 1255 a 1262 en la Corona de Castilla, in "Anuario de Estudios Medievales", 19 (1989), pp. 243-270.
} 
praticados por ocasião da morte dos reis. Devemos associá-la ao seu cuidado em referir os seus túmulos, conforme já vimos no parágrafo anterior.

Poderia pensar-se que a associação da morte dos reis com perturbações da natureza se filiava em crenças populares que se foram dissipando com o tempo. Mas no princípio do século XVI ainda se encontram vestígios dela. Tomemos, por exemplo, a descrição da morte de D. João I, feita por Rui de Pina na Crónica de D. Duarte. Começa jor acentuar o facto maravilhoso de o rei ter morrido exactamente no dia em que fazia setenta e seis anos de idade e em que comemorava o quadragésimo sexto aniversário da batalha de Aljubarrota e o décimo oitavo do dia em que tinha partido de Lisboa para ir conquistar Ceuta (coincidência, diga-se da passagem, forçada pelo cronista, como mostrou Armindo de Sousa ${ }^{28}$ ). Depois acrescenta: "No qual dia do seu fallecimento o Sol foi crys em grande parte da sua claridade [isto é houve um eclipse parcial do sol], e assi tambem foi o Sol crys ho dia que a Rainha Dona Felipa sua mulher falloceo primeiro que elle em Sacavem, e assi ho dia em que seu filho El Rey Dom Duarte seu filho mayor, e herdeiro falleceu depois em Tomar" (cap. 1, ed. Lopes de Almeida, 1977, p. 489). Quer dizer, portanto, que a natureza se associou também ao luto por meio do eclipse do sol, ou seja, por meio de uma perturbação cósmica que em pleno dia lançou as trevas sobre o mundo. Note-se, porém, que o contexto desta informação leva a interpretar o facto mais como uma espécie de homenagem cósmica aos defuntos do que de uma anomalia ameaçadora ou de um sinal de desordens sociais. De facto não se fala em desordens ou não se associam à morte dos reis. $O$ luto que os vassalos do rei praticam é também espectacular: "E do pranto e lamentações que ao tempo de sua morte os infantes seus filhos, por mingua de tal padre, e os vassallos por perda de tal rei deviam fazer, cesso de as especificar, somente saiba-se que em caso, em que as mortes dos reis e principes geralmente se fazem sempre signaes de grandes sentimentos, na d'este glorioso rei assi em prantos como em lagrimas, como na tristeza das vestiduras de todos, se fez por muitos dias com grande especialidade de dôr, que o reino foi todo coberto de vaso de burel" (ibid., p. 490).

As crenças na perturbação cósmica causada pela morte dos reis manifestam-se, porém, de muitas maneiras. Os Anais quatrocentistas de Santa Cruz de Coimbra dizem a respeito da morte de Afonso IV: "Era de

${ }^{28}$ Armindo de SOUSA, 1984; cf. L. ADÃO DA FONSECA, 1993, pp. 517-520. 
mil iii's IRb morreo el rey dom Affonso e tremeo a terra todo esse anno"29. O autor desconhecido do Livro dos Arautos, que escrevia por volta de 1416, refere a crença de que o escudo de Afonso Henriques que estava suspendido, como uma relíquia sobre o túmulo do mesmo rei, em Santa Cruz de Coimbra, caía no chão de cada vez que o rei de Portugal, seu sucessor, morria ${ }^{30}$. É possível que a crença tivesse sido originada justamente pela coincidência do referido terramoto com a morte de Afonso IV; o mais interessante, porém, é ter-se generalizado a convicção de que a morte de um rei traria sempre consigo um fenómeno físico como aquele.

Temos de concluir destes textos que as crenças e costumes pressupostos por João de Osma, por Rodrigo de Toledo, por Afonso X e pelo Conde D. Pedro, continuavam, no essencial, em pleno vigor, no tempo em que Rui de Pina escrevia a sua crónica, por volta do ano de 1500.

Trinta anos mais tarde, parece encontrar-se uma atitude completamente diferente em Garcia de Resende. Apesar de descrever com muitos pormenores a morte de D. João II, e de acentuar todos os episódios que poderiam contribuir para lhe dar um carácter edificante, pouco diz sobre o luto que se fez no reino e não menciona o mínimo indício de perturbação cósmica ou social. As cerimónias fúnebres prendem longamente a sua atenção, mas mal se refere a prantos e lamentações populares, excepto quando foi sepultado em Silves, antes de ser transladado para a Batalha ${ }^{31}$. Embora o relato que faz da transladação do corpo do rei, cinco ano depois da sua morte, seja, no género, um das mais pormenorizados e completos de toda a historiografia portuguesa, não se encontra nele senão uma brevíssima referência a prantos fúnebres, mais como reacção sentimental aos cânticos litúrgicos do que como manifestação de dor $^{32}$. Pelo contrário, torna-se evidente que o cronista pretende acumular toda a espécie de indícios, em

${ }^{29}$ Ed. António CRUZ, Anais, crónicas e memórias avulsas de Santa Cruz de Coimbra, Porto, 1968, p. 91.

30" Dicitur eciam generaliter quod cum regem dicti regni Portugalie debitum nature sequi contigit quamuis multum distet illud scutum in dicto monasterio pendens cadit, quo signo decessus regis noscitur" (ed. AIRES NASCIMENTO, 1977, p. 251).

3 " Foy o corpo del Rey leuado em $\mathrm{h} \sim$ ua tumba [...] á Se de Sylues com muyta tristeza, e muyto grandes prantos dos senhores, e fidalgos, caualleiros, e pouos que ally erão, e acompanhauão" (cap. 214, ed. 1798, p. 287).

32" E tanto que deceram o primeiro degrao da hessa começaram os cantores ho cantico de Zacharias, Benedictus Dominus Deus Israel, com tantas vozes, e estromentos, e deuaçam, que nāo auia pessoa que não chorasse" (Tresladaçam do corpo do [...] rey Dom Ioam o Segundo, ibid., p. 295). 
palavras, gestos e atitudes em que se revela a edificante serenidade pessoal do rei perante a morte, a extraordinária dignidade das suas exéquias e sobretudo a espectacularidade da sua transladação. $O$ poder que a morte do rei revela transparece em emoções de grande intensidade, mas sempre edificantes e sem que ele perca a sua admirável lucidez e uma enorme presença de espírito, como se fosse verdadeiramente sobrehumano: é um poder inseparável da sua própria pessoa. Não é, portanto, transmissível, ao contrário do que acontece com a coroa e com o reino. Mas é exemplar, e por isso digno de imitação. Por outro lado, o que D. Manuel, seu sucessor, manifesta na transladação, destina-se a venerar o rei morto, mas ao mesmo tempo, e talvez sobretudo, a ostentar uma grandiosidade que beneficia antes de mais quem concebe e organiza as cerimónias fúnebres, ou seja ele próprio e a realeza. Seja como for, o poder régio apresenta-se, tanto num caso como no outro, como capaz de dominar a natureza cósmica e o corpo social do reino. Não existe qualquer espécie de perturbação, apesar de o sucessor não ser filho do rei falecido e de este ter perdido o seu herdeiro natural em circunstâncias dramáticas. $O$ poder régio julga-se agora capaz de dominar a morte. $\mathrm{O}$ desaparecimento do seu detentor terreno não lhe traz nenhuma espécie de abalo ou diminuição. Parece que o corpo do reino não tem qualquer razão para temer a morte do rei.

E todavia talvez as crenças populares não tivessem desaparecido tão facilmente como isso, mesmo nesta porção da Europa, onde não encontrei outros testemunhos delas.

Transportemo-nos a Londres sessenta anos mais tarde. Shakespeare está no princípio da sua carreira de dramaturgo e obtém o maior sucesso com os seus primeiros dramas históricos, inspirados na história dos reis de Inglaterra dos fins do século XIV e do princípio do século XV, do tempo da Guerra das Duas Rosas e da Guerra dos Cem Anos. Transpõe para o teatro as suas concepções sobre a realeza. Estas são tão expressivas que inspiraram a Kantorowicz o seu genial comentário a The tragedy of king Richard II no princípio de Os dois corpos do rei. O seu profundo conhecimento das obras jurídicas medievais permite-lhe mostrar que a ficção sobre os dois corpos do rei não é de modo algum uma invenção teatral ou um processo retórico, e que as suas fórmulas literárias representam uma excelente dramatização de 
crenças e concepções muito antigas ${ }^{33}$. O historiador alemão não parece, porém, ter notado, ou não se interessou por dois passos dos dramas de Shakespeare que testemunham a crença popular naquilo a que chamei o "luto cósmico". As referências a ele são bem expressivas e aparecem pelo menos em duas ocasiões, uma no Ricardo II, outra na segunda parte do Henrique IV. Mas figuram também em algumas das tragédias, onde a acção é mais inspirada pelas contradiçōes do comportamento humano do que pela doutrina do poder.

A primeira, no Ricardo II, surge na boca do capitão galês, e é, por isso mesmo, a expressão de um soldado anónimo que representa as convicçōes populares. A cena passa-se num campo do País de Gales, pouco tempo depois de o revoltado duque de Bolingbroke, futuro Henrique IV, ter desembarcado em Inglaterra. "Pensa-se", diz ele "que o rei já morreu. Nós não queremos esperar mais tempo. Os loureiros da nossa terra estão todos murchos e os meteoros aterrorizam as estrelas fixas do céu. A pálida lua brilha sangrenta sobre a terra e os profetas de rosto descarnado murmuram formidáveis mudanças; os ricos têm um ar triste e os miseráveis dansam e saltam de alegria: uns têm medo de perder a sua fortuna e os outros esperam alcançá-la por meio dos furores da guerra. Estes sinais são os que anunciam a morte ou a queda dos reis. Adeus. Os meus compatriotas partiram e fugiram, convencidos de que Ricardo, o seu rei, já morreu". O conde de Salisbury, mostrando que partilha das mesmas conviç̧ōes, responde: "Ah, Ricardo! É com o olhar de uma alma perturbada que vejo a tua glória, como uma estrela cadente cair do firmamento sobre a terra abjecta! O teu sol esconde-se, chorando, no fundo do ocidente, anunciando as tempestades eminentes, a desgraça e a desordem. Os teus amigos fugiram para se juntarem aos teus inimigos. Todos os destinos avançam contra a tua fortuna" (acto II, cena 4, trad. La Pléiade, I, p. 567).

A segunda citação aparece no Henrique IV. É mais concisa do que a anterior, nem por isso menos clara: $O$ rei Henrique IV, justamente o duque de Bolingbroke, que tinha sucedido a Ricardo II depois de combater contra ele, estava gravemente doente quando, por sua vez, teve de defrontar a revolta de alguns dos que o tinham colocado no trono. Acabava de se dar a batalha que lhe garantiu o triunfo. Mas quando trouxeram a notícia ao rei

\footnotetext{
${ }^{33}$ A obra de KANTOROWICZ, 1985 (1957) começa justamente por um longo comentário ao drama de Ricardo II: pp. 35-52.
} 
mostrou-se a gravidade da doença, porque ele desmaiou nesse momento. E logo o seu filho Humphrey exclama, mostrando que tinha percebido a eminência da morte: "Os povos alarmam-me: observaram criaturas sem pai, nascimentos contra a natureza. As estações do ano mudaram de sentido, como se $o$ ano tivesse achado alguns meses adormecidos e os tivesse ultrapassado de um salto". Clarence, o outro filho, acrescenta: "O rio teve três fluxos, sem nenhum refluxo intermediário. E os velhos, crónicos saudosos do passado, dizem que o mesmo aconteceu pouco tempo antes de nosso avô Eduardo ter caído doente e ter morrido" (acto IV, cena 4, trad. La Pléiade, I, p. 734).

Nas tragédias as referências às perturbações da ordem natural que precedem a morte dos reis são ainda mais expressivas e desempenham uma função essencial no texto para criarem um clima de grande intensidade dramática. É o que acontece sobretudo em Júlio César, que não é um rei, mas estava prestes a ser coroado, que em várias ocasiões é chamado príncipe, e que, em todo o caso, é o protótipo do chefe cujo poder não conhece limites. O significado destas referências é, de resto, perfeitamente sublinhado por um passo do Hamlet, que, por isso, convém citar primeiro. Aparece na boca de Horácio, o amigo do protagonista principal, que interpreta assim o aparecimento do espectro do rei assassinado: "Em Roma, no tempo do seu glorioso apogeu, pouco antes da queda do poderoso César, os mortos vestidos com as suas mortalhas, saindo dos seus túmulos, espalharam os seus murmúrios pelas ruas; viram-se estrelas com caudas de fogo, geadas de sangue, um sol aterrador, e o astro húmido que comanda as marés empalideceu até se eclipsar, como no dia do juízo. Estes mesmos sinais precursores de acontecimentos trágicos, anunciadores de catástrofes e mensageiros de destinos, foram oferecidos à nossa pátria pela terra e pelo céu" (Acto I, cena 1, trad. La Pléiade, II, p. 617). Os acontecimentos a que Horácio se referia anunciam de facto o assassinato da rainha e do rei da Dinamarca pelo próprio Hamlet. O rei já o temia. Por isso, para justificar o afastamento de Hamlet para Inglaterra afirma: "A segurança do nosso Estado não poderia jamais admitir os perigosos acasos a que as suas loucuras nos expõem". Rosencrantz, o vassalo, confirma esta decisão invocando como razão o interesse do reino, vivamente ameaçado pela morte do rei: "[...] A majestade não morre nunca sosinha; o turbilhão da sua queda arrasta para 0 abismo tudo o que a rodeia. É como uma grande roda que gira acima dos montes mais altos; aos seus enormes raios estão ligados milhares de ser ínfimos, que a queda do orbe arrasta imediatamente consigo, com os seus 
corpos e os seus bens, para a estrondosa ruína. Basta o rei suspirar, que logo todo o reino geme" (Acto III, cena 3, ibid., p. 664).

Não é preciso, portanto, citar as longas e variadas passagens de Júlio César em que se descrevem as terríveis desordens cósmicas que anunciam a sua morte. Basta apenas lembrar as palavras de Calpúrnia, a mulher de César, que tenta dissuadi-lo de se apresentar no Capitólio, devido aos terríveis preságios que acabava de descrever: "Quando morre um mendigo ninguém vê cometa nenhum; mas por causa da morte dos príncipes até o próprio céu se torna em fogo" (Acto II, cena 2, trad. La Pléiade, II, p. 575; cf. ibid., pp. 565, 566, 572, 576).

Mencionemos, para terminar, no Macbeth, as desordens naturais observadas pelo nobre Lenox e que, sem ele saber, anunciavam o assassinato do rei Duncan: "A noite estava agitada. No lugar onde dormíamos, as chaminés foram derrubadas pelo vento; diz-se que se ouviram lamentações no ar, estranhos gritos de morte, vozes que anunciavam, con terríveis gemidos, pavorosos tumultos e acontecimentos confusos que iriam suceder nestes dias de desgraça. A ave das trevas piou toda a noite. Alguns afirmam que a terra tinha febre e tremia..." (Acto II, cena 3, trad. La Pléiade, p. 972).

Estas passagens de Shakespeare não deixam lugar a dúvidas: na Inglaterra do fim do século XVI acreditava-se ainda que a morte dos reis era anunciada e trazia consigo a subversão da natureza. A centralização do poder régio e o fortalecimento da monarquia tinham porventura feito crer a alguns teóricos da sua permanência que ela não podia sofrer perturbação com a morte do seu detentor. Os juristas e pensadores políticos que construíram, nas suas variadas formas e expressões, a doutrina dos dois corpos do rei, tinham querido, justamente, dissipar as angústias e perturbações colectivas causadas pelo desaparecimento dos detentores do poder. Os mestres de cerimónias e chefes do protocolo cortesão esforçavam-se por substituir o dramatismo emocional dos prantos e lamentaçōes rituais pelo espectáculo da ostentação do poder, em exéquias cada vez mais pomposas. Todavia, os povos, que temiam e eram vítimas das desordens que as sucessões tantas vezes acarretam, continuavam a exprimir os seus receios atribuindo à natureza convulsões aterradoras. 
Ou seja, ao contrário do que Garcia de Resende provavelmente queria dizer, e ao contrário do que todos os reis tentaram demonstrar assegurando a sucessão imediata e encenando a imortalidade do poder, os povos continuavam a temer que a morte do rei trouxesse, pelo contrário, a morte do mesmo poder. Não, obviamente porque desejassem o poder por si mesmo, mas porque não pediam conceber a paz e a segurança sem que alguém assegurasse o seu exercício. Continuavam a desconfiar, se assim me posso exprimir, do poder do próprio poder. As suas crenças no luto cósmico mostram que não acreditavam facilmente que «o poder é mais forte do que a morte». Com toda a razão, creio eu: porque apesar de todas as formas que o poder inventou para se reproduzir ou para fazer crer na sua imortalidade, nunca foi capaz de permanecer inalterável. De facto a única coisa que é mais forte do que a morte é mesmo o amor. Assim o diz o Cântico dos Cânticos e assim o demonstra a própria História.

\section{BIBLIOGRAFIA}

ARIÈs, Philippe, L'homme devant la mort, Paris, Éd. du Seuil, 1977.

Brown, Elizabeth A. R. , Death and the Human Body in the Later Middle Ages: The Legislation of Boniface VIII on the Division of the Corpse, in "Viator", 12 (1981), pp. 221-270.

ID., The Ceremonial of Royal Succession in Capetian France: The Double Funeral of Louis $X$, in "Traditio", 34 (1978), pp. 227-271.

ID., The Ceremonial of Royal Succession in Capetian France: The Funeral of Philip $V$, in "Speculum", 55 (1980), pp. 266-293.

ID., Burying nd Unburying the Kings of France, in Richard C. Trexler (ed.), Persons in Groups: Social Behavior As Identity Formation in Medieval and Renaissance Europe, Binghamton, Center for Medieval and Early Rena issance Studies, 1985, pp. 241-266.

Caetano, Marcelo, História do Direito português, Lisboa, ed. Verbo, 1981.

Crónica geral de Espanha de 1344 (ed. crítica do textos português por L. F. Lindley CINTRA), vols. I a IV, Lisboa, Academia Portuguesa da História, 1951-1990.

Crónica latina de los reyes de Castilla. Introd., texto crítico, trad., notas e indices de Luis Charlo BREA, Universidad de Cadiz, 1984.

Crónica dos sete primeiros reis de Portugal (ed. crítica por Carlos da Silva TARouCA), Vols. I a III, Lisboa, Academia Portuguesa da História, 1952.

Cruz, António (ed.), Anais, crónicas e memórias avulsas de Santa Cruz de Coimbra, Porto, Biblioteca Municipal, 1968.

Fernao Lopes, Crónica do rei D. Pedro I (texte établi par G. MaCChI, introd., trad. et notes par J. STEUNON, Ed. du CNRS, 1985). 
ID., Crónica de D. Fernando. Edição crítica por Giuliano MACCHI, Lisboa, Imprensa Nacional, [1975].

FONSECA, Luís Adão da, A morte como tema de propaganda política na historiografia e na poesia portuguesa do século XV, in "Biblos", 69 (1993), pp. 507-538.

FRITZ, Paul S., From 'Public' to 'Private': The Royal Funerals in England, 15001830, in Joachim Whaley (ed.), Mirrors of Mortality. Studies in the Social History of Death, London, Eyropa Publications, 1981, pp. 61-79.

GaRCIA PElayo, Manuel, Los mitos políticos, Madrid, Alianza ed., 1981.

Gomes, Saul António, Percursos em torno do panteão quatrocentista de Avis, in "Biblos", 70 (1994), pp. 197-242.

HERTZ, Robert, Contribución a un estudio sobre la representación colectiva de la muerte, in Id., La muerte y la mano derecha, Madrid, Alianza Universidad, 1990, pp. 14-102 (trad. do original francês de 1917).

KANTOROWICZ, Ernst H., Los dos cuerpos del rey. Un estudio de teología política medieval, Madrid, Alianza ed., 1985 (trad. do original inglès de 1957).

MatToso, José, A morte dos reis na cronistica pré-afonsina, in "Estudos medievais", 10 (1993), pp. 79-96.

MITRE FERNÁNDEZ, Emilio, La muerte del rey: la historiografia hispánica (12001348) y la muerte entre las élites, in "En la España medieval", 11 (1988), pp. 167-184.

NIETO SORIA, José Manuel, Fundamentos ideológicos del poder real en Castilla (siglos XIII-XVI), Madrid, Eudema, 1988.

ID., Ceremonias de la realeza. Propaganda y legitimación en la Castilla Trastámara, Madrid, 1993.

Primera crónica general de España, ed. por Ramón MENÉNDEZ PIDAL, con un estudio actualizador de Diego CATALÁN, Madrid, Ed. Gredos, 1977.

RESENDE, Garcia de, Crónica de D. João II e Miscelânea. Reimpressão fac-similada da nova edição conforme a de 1798. Prefácio de J. Veríssimo SERRẢO, Lisboa, Imprensa Nacional, 1991.

Rodrigo DE TOledo (Rodrigo Ximénez DE RADA), Opera (ed. card. F. de LORENZANA, Madrid, 1793), reimpresión facsímil con indices por M. Desamparados CABANes PeCourt, Valéncia, 1968.

SÁNCHEZ ALBORNOZ, Claudio, La sucesión al trono en los reinos de León y Castilla, in Id., Estudio sobre las instituciones medievales españolas, México, Universidad Nacional Autónoma, 1965, pp. 639-704.

SCHMITT, Jean-Claude, Les morts et le pouvoir, in ID., Les revenants. Les vivants et les morts dans la société médiévale, Paris, Gallimard, 1994, pp.175-196.

ShAKESPEARE, Oeuvres complètes. Avant-propos d'André Gide. Introd. générale et textes de présentation d'Henti Fluchère, [trad. de François-Victor Hugo], 2 vols., Paris, Gallimard, [1959],

Sousa, Armindo de, $A$ morte de D. João I (um tema de propaganda dinástica), Porto, Centro de Estudos Humanísticos, 1984.

ThомAS, Louis-Vincent, Anthropologie de la mort, Paris, Payot, 1980. 


\section{RÉSUMÉ}

Comme l'a montré R. Hertz, la mort d'un chef constitue, pour une communauté d'une société traditionnelle, l'occasion d'un tres grand trouble. Elle craint alors la désagregation et la faiblesse devant les menaces extérieures ou bien la propagation de la mort à l'intérieur de la communauté. Cette réaction explique la force avec laquelle se présentent tous les signes destinés à démontrer la continuité du pouvoir et à cultiver sa mémoire. Cella explique l'attention accordée par les chroniques hispaniques aux tombeaux royaux depuis celui d'Alphonse II, l'affirmation de l'origine divine du pouvoir royal et aussi les croyances sur la perturbation cosmique et sociale survenue lors de la mort de certains rois. L'intensité des manifestations de deuil devient une façon de surmonter le trouble causé par la mort. Cette croyance, attestée encore sous une forme très dramatique par Shakespeare dans plusieurs de ses pièces, semble disparaître au Portugal vers la fin du $X^{e}$ siècle.

\section{SUMMARY}

As demonstrated by $\mathbf{R}$. Hertz, the death of a leader is, for a traditional society's community a time of great trauma. It creates the disunion and the weakness before exterior threats or the spreading of death within the community. This reaction explains the strength of the signs intended to demonstrate the continuity of power and the ones that cultivate its memory. This explains the attention given by hispanic chronicles to the royal tombs since the one of Afonso II, the affirmation of the divine origine of the royal power and also the beliefs about the cosmic and social perturbations in conseqüence of the death of some kings. The mourning's manifestations intensity becomes a way of surpassing the trauma caused by death. Such a belief, represented in the most dramatic way by Shakespeare in several of his plays, seems to disappear in Portugal by the late fifteenth century. 